\title{
Research of ecological indicators of two-way vehicle in stationary conditions
}

ARTICLE INFO

Received: 6 August 2021

Revised: 25 August 2021

Accepted: 12 September 2021

Available online: 15 September 2021
The presented article concerns the research on the emission of pollutants of a rail-road tractor in two stationary research tests. The purpose of the tests was to carry out control tests of pollutant emissions and their analysis. The object used during the works was approved in accordance with the Stage V standard, which requires measurements of emissivity both in stationary, dynamic and real conditions. Despite the requirement to test engines installed on a vehicle during their normal duty cycle with PEMS, the emission limits measured in this test have not yet been defined. Therefore, the work below focuses on the stationary test cycle. The measurements were carried out in accordance with the internal combustion engine operating points described in the approval test, and then compared with the modernized NRSC test. It contains modified measuring points and rotational speeds of the crankshaft, adopted on the basis of the most common operating parameters of agricultural tractor combustion engines in real operating conditions. The measurements were performed with the use of a mobile dynamometer and devices for measuring emissions of harmful exhaust gas compounds and recording on-board data. In the performed test, the vehicle drive system worked at fixed operating points, with defined values of crankshaft rotational speed and load. Based on the recorded data on the concentrations of pollutants in the exhaust gases, the unit emission of the tested object was determined. In the final stage of the work, these data were used to perform a comparative analysis with the emission limits contained in the standard.

Key words: exhaust emission, rail-road vehicle, NRSC, PEMS, NRMM

This is an open access article under the CC BY license (http://creativecommons.org/licenses/BY/4.0/)

\section{Introduction}

One of the key factors contributing to the deterioration of the natural environment are combustion engines in means of transport, which are the source of exhaust gases. Research by the European Environment Agency shows that transport generates $20 \%$ of all global $\mathrm{CO}_{2}$ emissions, almost $10 \%$ of PM10 and $39 \%$ of $\mathrm{NO}_{\mathrm{x}}$ [5]. Despite the introduction of increasingly more stringent exhaust emission norms, the number of vehicles in use is increasing annually, which obviously affects the air quality. This contributes to the formation of smog in urban agglomerations and causes climate change as a result of the greenhouse gases (GHG) released. According to World Health Organization (WHO) reports, over $90 \%$ of the world's population lives in regions where the limits of harmful compounds concentration in the air are exceeded [20]. Our World in Data research team has shown that in 2017, air pollution was the fourth largest in terms of numbers (after high blood pressure, smoking, high blood sugar and obesity) cause of illness and death or disability in the world. It is estimated that 3.4 million people died prematurely as a result of this pollution, which accounts for about $6 \%$ of deaths worldwide. This indicates that it is one of the world's biggest health and environmental problems to date [12].

Off-road vehicles have a significant impact on the environmental pollution due to their operating characteristics and how they are used [6]. The main problem of these types of vehicle is the type-approval tests carried out on an engine dynamometer. The literature widely describes the problem of the unrepresentativeness of laboratory tests performed on specially prepared measuring stands $[9,11$, $13,16,18,19]$. In this type of test, the real operating conditions of the vehicles are simulated in standardized tests. It has been shown, however [7, 8, 14, 15, 17], that the test cycles used in type approval do not reflect the real conditions of the engine's actual operation. This is mainly due to the wide variety and diversity among machines and vehicles classified under the NRMM (Non-Road Mobile Machinery) group. This contributes to the differences between the qualitative and quantitative measurements of exhaust emissions in stationary tests and the real exhaust emissions in operation. In order to obtain reliable results, it becomes necessary to conduct field work on real objects performing real tasks. Currently, road tests are compulsory for passenger cars and heavy vehicles all over the world. Measurements in RDE (Real Driving Emissions) tests are performed using specialized exhaust gas analyzers from the PEMS group (Portable Emissions Measurement Systems). This makes it possible to perform reliable measurements in real operating conditions, and thus to verify the ecological indicators of vehicles in a wide spectrum of operation of their drive systems.

Based on the NRSC (Non-Road Stationary Cycle) test and field measurements, it is possible to modify and adjust the current test procedures. A set of changes to the static engine tests were proposed in [6], based on the similarity of the operating conditions of the engines, and where the phase coordinates were selected arbitrarily based on the author's knowledge and experience. This test was described in more detail and used to conduct comparative analyzes in the section discussing the measurement results.

\section{Method}

A rail-road tractor was used for the tests (Fig. 1, Table 1) equipped with a 6-cylinder VGT (Variable Turbo Geometry) turbocharged engine with a displacement of $6.8 \mathrm{dm}^{3}$ and a maximum power of $107 \mathrm{~kW}$ at $2000 \mathrm{rpm}$. The maximum torque of the engine was $640 \mathrm{Nm}$ at $1500 \mathrm{rpm}$. The engine was supplied by direct injection of Common Rail 
fuel at a pressure of 1800 bar. It should also be noted that the tractor was equipped with a continuously variable transmission, which was a combination of a two-stage planetary gear, a clutch assembly and a hydrostatic transmission. This solution to optimize the power flow, and additionally boasts a simple design and two internally changed gears. According to the manufacturer's data, the vehicle complied with the Stage V exhaust emission norm. It was equipped with an EGR (Exhaust Gas Recirculation) system, so that part of the engine exhaust is mixed with the intake air in the form of exhaust gas recirculation. As a result, the combustion process in the engine is slower and, at the same time, its temperature is lower. The vehicle also had a DOC (Diesel Oxidation Catalyst) and DPF (Diesel Particulate Filter) system, allowing for the reduction of both hydrocarbon and particulate emissions in the exhaust gas. In addition, the vehicle also uses SCR (Selective Catalytic Reduction) to reduce the content of nitrogen oxides in the exhaust gases, which are converted into nitrogen and water vapor using an aqueous solution of urea (Adblue).

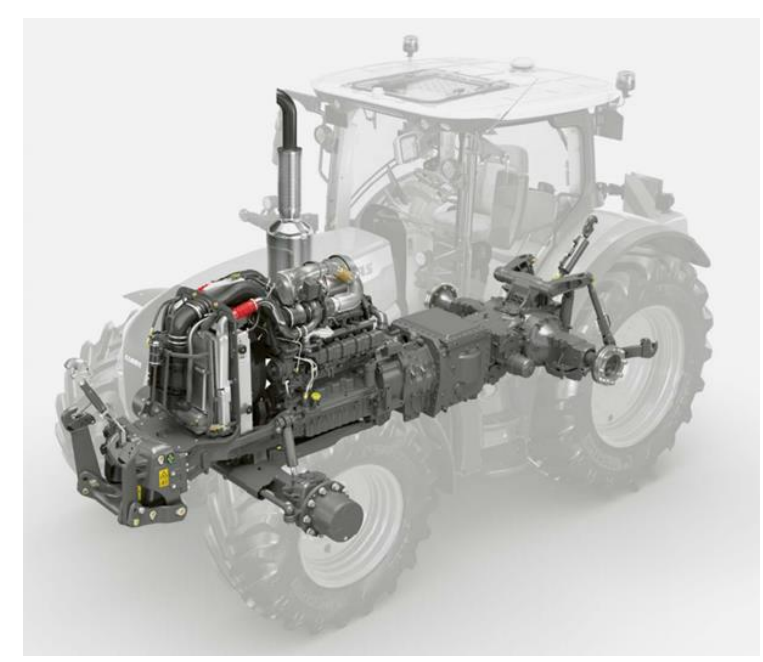

Fig. 1. Test vehicle with the drive system highlighted [10]

Table 1. The main technical parameters of the test vehicle [10]

\begin{tabular}{|l|c|}
\hline \multicolumn{2}{|c|}{ Vehicle parameters data sheet } \\
\hline Engine type & Diesel \\
\hline Fuel supply system & Common Rail \\
\hline Number of cylinders & $6.8 \mathrm{dm}^{3}$ \\
\hline Displacement & $107 \mathrm{~kW} / 2000 \mathrm{rpm}$ \\
\hline Nominal power at engine speed & $640 \mathrm{Nm} / 1500 \mathrm{rpm}$ \\
\hline Nominal torque at engine speed & VGT \\
\hline Turbocharging & EGR, DOC, DPF, SCR \\
\hline Exhaust aftertreatment systems & Stage V \\
\hline Exhaust emission norm & \\
\hline
\end{tabular}

The aim of the research was to determine the differences in the exhaust emissions measurements carried out in stationary conditions. The vehicle was tested according to two different measurement test methods, and the actual ecological indicators of the test vehicle were determined based on the comparative analysis of the results obtained from these tests. As shown in [7, 8, 14, 15, 17] tests carried out in laboratory conditions on engine dynamometers and test benches do not reflect the real exhaust emission values that occur in real vehicle operation. The NRSC test procedures according to which off-road vehicles are normally tested do not sufficiently reflect the actual engine operating parameters.

The test vehicle was connected with a mobile dynamometer using a power take-off (PTO) shaft, which made it possible to set the engine to achieve assigned operating points (Fig. 2 (II)). The dynamometer was equipped with an air-cooled electric machine (generator), which enabled a two-way power take-off. The maximum dynamometer rotational speed was $3600 \mathrm{rpm}$ and the maximum received torque was $7200 \mathrm{Nm}$. The engine operating parameters read from the on-board diagnostics system were recorded using the TEXA Navigator TXT device. Additionally, during the tests, the emission of pollutants from exhaust gases was measured with the use of devices from the PEMS group (Fig. 2 (I))

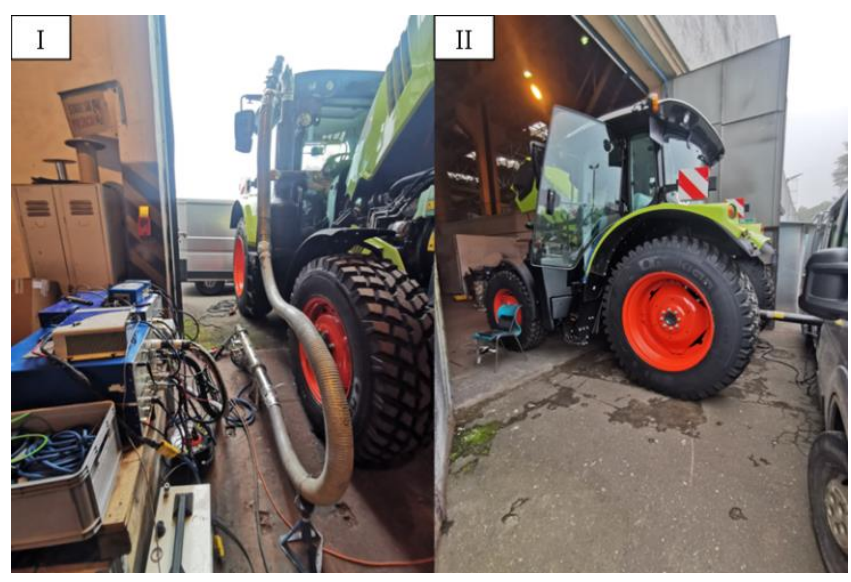

Fig. 2. Test stand: I - exhaust emissions measurement device, II - connection between the PTO and the mobile dynamometer

\section{Results}

The exhaust emission measurements of toxic gases was carried out in the process of performing two measurement tests. The first was the stationary NRSC test cycle used for testing off-road machines (Fig. 3, Table 2). It is a part of the Stage I, II, III A, III B and IV exhaust emission norms for diesel engines with a net power of $19 \mathrm{~kW} \leq \mathrm{P} \leq 560 \mathrm{~kW}$, operating at constant or variable speeds. It consists of 8 phases of different rotational speed and load points, which are chosen to correspond with the typical operating range of diesel engines in machines of this type $[1,2,4]$.

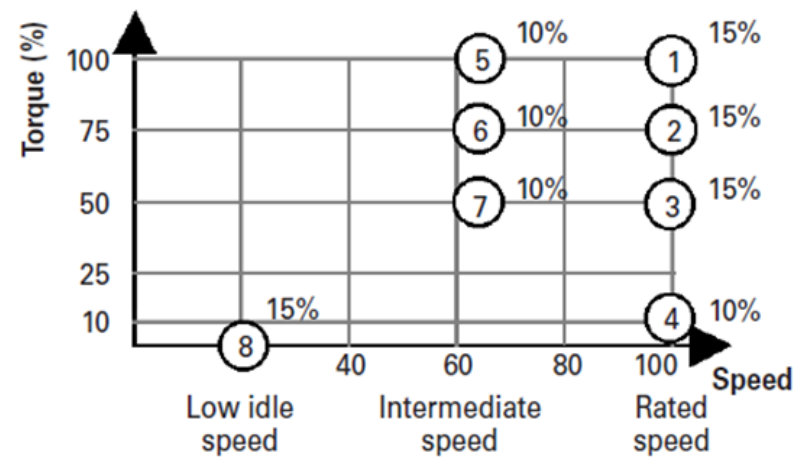

Fig. 3. NRSC test procedure measurement points (test 1) [3] 
Table 2. The NRSC test parameters [3]

\begin{tabular}{|c|c|c|c|c|c|c|c|c|}
\hline Parameters & \multicolumn{7}{|c|}{ Test phase number } \\
\hline & 1 & 2 & 3 & 4 & 5 & 6 & 7 & 8 \\
\hline load [\%] & 100 & 75 & 50 & 10 & 100 & 75 & 50 & 0 \\
\hline $\begin{array}{c}\text { load } \\
{[\mathrm{Nm}]}\end{array}$ & $\mathbf{4 6 5}$ & $\mathbf{3 5 0}$ & $\mathbf{2 3 0}$ & $\mathbf{4 5}$ & $\mathbf{6 0 0}$ & $\mathbf{4 2 5}$ & $\mathbf{3 0 0}$ & $\mathbf{0}$ \\
\hline $\mathrm{n}$ & \multicolumn{6}{|c|}{$\mathrm{n}_{\text {rated }}$} & \multicolumn{5}{|c|}{$\mathrm{n}_{\text {intermediate }}$} & $\mathrm{n}_{\text {idle }}$ \\
\hline $\mathrm{n}[\mathrm{rpm}]$ & \multicolumn{6}{|c|}{$\mathbf{2 0 0 0}$} & \multicolumn{5}{|c|}{$\mathbf{1 2 0 0}$} & $\mathbf{8 0 0}$ \\
\hline $\begin{array}{c}\text { Phase } \\
\text { weighing } \\
\text { factor }\end{array}$ & 0.15 & 0.15 & 0.15 & 0.10 & 0.10 & 0.10 & 0.10 & 0.15 \\
\hline
\end{tabular}

The rail-road tractor was also tested in accordance with the modified NRSC test for all engines (Fig. 4, Table 3). The modified version of the NRSC test was developed by Lijewski [6]. Proposition (II) results from the combination of two tests taking into account the individual character of the engine operation for the tested vehicles. The first group consists of engines which, in real operating conditions, operate in the entire rotational speed range. The second group consists of engines operating typically at a constant rotational speeds. This test was chosen because agricultural tractors belong to both engine groups simultaneously, depending on how the vehicle is used and which type of task it performs. The procedure consisted of 7 speed and load phases which depend on the engine used.

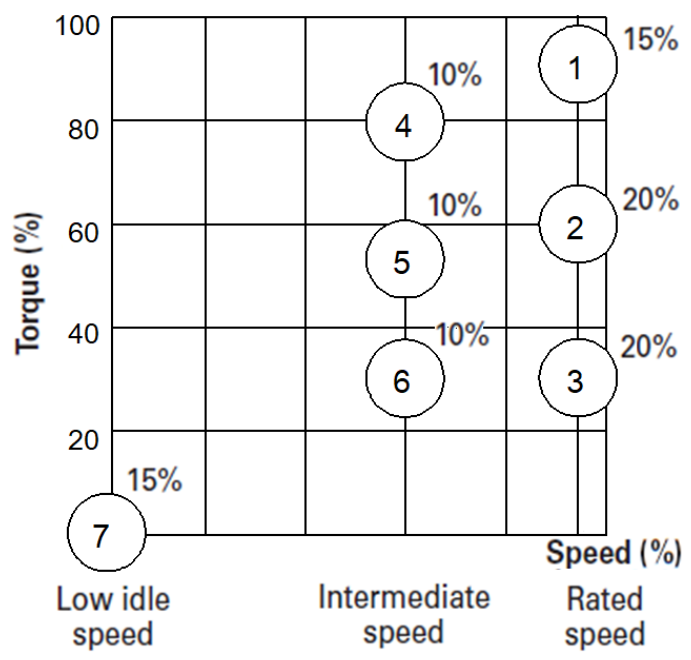

Fig. 4. The modified NRSC test (test 2) [6]

Table 3. Parameters of the modified NRSC test designed for all engines [6]

\begin{tabular}{|c|c|c|c|c|c|c|c|}
\hline Parameters & \multicolumn{7}{|c|}{ Test phase number } \\
\hline & 1 & 2 & 3 & 4 & 5 & 6 & 7 \\
\hline load [\%] & 90 & 60 & 30 & 80 & 55 & 30 & 0 \\
\hline load [Nm] & 420 & 280 & 135 & 475 & 320 & 175 & $\mathbf{0}$ \\
\hline $\mathrm{n}$ & \multicolumn{3}{|c|}{$\mathrm{n}_{\text {rated }}$} & \multicolumn{3}{|c|}{$\mathrm{n}_{\text {intermediate }}$} & $\mathrm{n}_{\text {idle }}$ \\
\hline $\mathrm{n}[\mathrm{rpm}]$ & \multicolumn{3}{|c|}{2000} & \multicolumn{3}{|c|}{1200} & 800 \\
\hline $\begin{array}{l}\text { Phase weigh- } \\
\text { ing factor }\end{array}$ & 0.15 & 0.20 & 0.20 & 0.10 & 0.10 & 0.10 & 0.15 \\
\hline
\end{tabular}

Based on the performed measurements, carried out in the above-mentioned test phases, the characteristics of the time-variable exhaust emission of harmful exhaust compounds limited by the emission norms were created assigned to the defined engine operating points. From the obtained results, a similarity in the way the results are distributed could be observed. In both cases, there is a down- ward trend for each of the monitored toxic exhaust compounds. Thus, it can be concluded that the resulting exhaust emission was closely related to the rotational speed and the load of the vehicle engine. The obtained results differed, however, to some extent. In the case of the modified NRSC test, the obtained results were about $30 \%$ lower than in the NRSC homologation test. These deviances were $27.8 \%$ for carbon monoxide, $34.2 \%$ for nitrogen oxides and hydrocarbons, and $30.3 \%$ for particulate matter, respectively. This was due to the fact that the load for all the tested phases, as defined in test 2 , was characterized by lower values. The characteristics have been shown in Figs 5 and 6. For better clarity of the results, the PM values were multiplied by 10000.

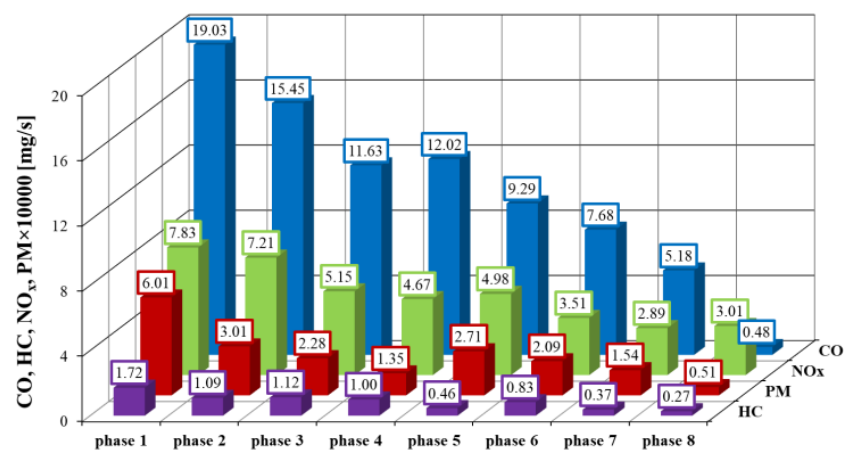

Fig. 5. Exhaust emission characteristics in each second obtained in the NRSC test

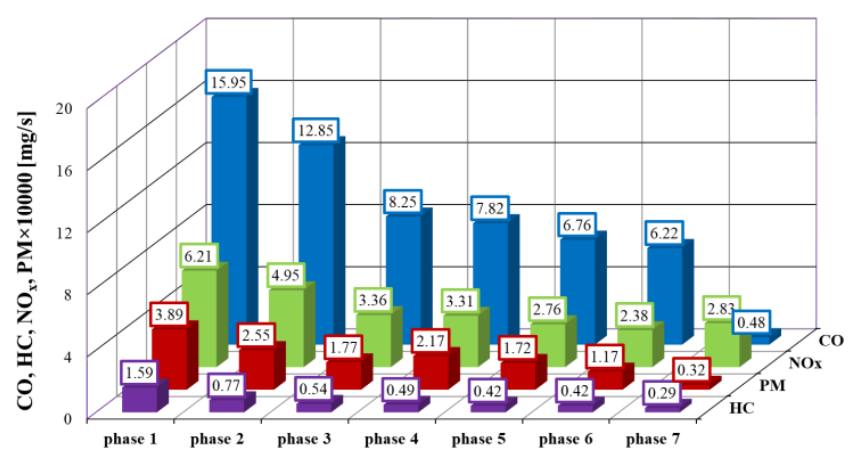

Fig. 6. Exhaust emission characteristics in each second obtained in the modified NRSC test

The performed analysis was supplemented with the characteristics of the specific emissions obtained in the entire tests, together with the reference to the Stage V emission norm for engines in the power range $56 \leq \mathrm{P}<130 \mathrm{~kW}$, based on which the test vehicle received type approval (Fig. 7). The obtained results show that the Lijewski test (test 1) shows a more favorable exhaust emission values of all toxic gas compounds per unit of work. The smallest difference (9.2\%) was obtained for hydrocarbons. The value for test 1 was $0.25 \mathrm{~g} / \mathrm{kWh}$ and for test 2 it was $0.23 \mathrm{~g} / \mathrm{kWh}$. In both cases, the Stage V emission limit value of $5 \mathrm{~g} / \mathrm{kWh}$ was not met.

The largest difference $(29.3 \%)$ was found for particulate matter, the values were $5.01 \times 10^{-5} \mathrm{~g} / \mathrm{kWh}$ for the NSRC test and $3.54 \times 10^{-5} \mathrm{~g} / \mathrm{kWh}$ for the modified NRSC test, respectively. In both cases, the exhaust emission standard of 0.015 $\mathrm{g} / \mathrm{kWh}$ was met. For nitrogen oxides, the difference was 
$11 \%$, and for carbon monoxide $22 \%\left(2.35 \mathrm{~g} / \mathrm{kWh} \mathrm{NO}_{\mathrm{x}}, 1.26\right.$ $\mathrm{g} / \mathrm{kWh} \mathrm{CO}$ - test $1,2.09 \mathrm{~g} / \mathrm{kWh} \mathrm{NO}, 0.98 \mathrm{~g} / \mathrm{kWh} \mathrm{CO}$ - test 2). The limit values were $0.4 \mathrm{~g} / \mathrm{kWh}$ for $\mathrm{NO}_{\mathrm{x}}$ (not met in both tests) and $0.5 \mathrm{~g} / \mathrm{kWh}$ for $\mathrm{CO}$ (met in both tests), respectively. On the basis of the obtained results, it can therefore be concluded that using modified research tests characterized by different engine operating points to test off-road vehicles has scientific merit.

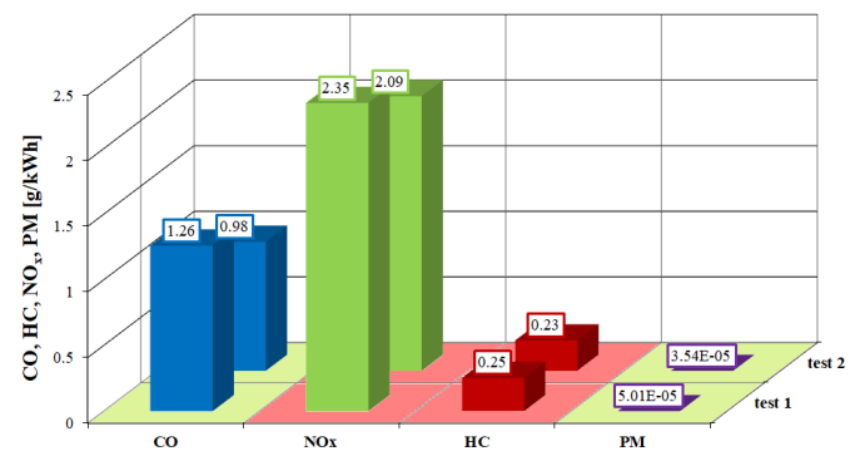

Fig. 7. Characteristic of the specific emission obtained in the tests

\section{Conclusions}

The considerations discussed in this article concern exhaust emission tests of toxic compounds during the engine dynamometer braking tests of an off-road vehicle. The eight-phase NRSC test and its modified original sevenphase variant were performed. As part of the research carried out, ecological indicators of the engine were determined, based on which a comparative analysis was conducted. The specific exhaust emission values of pollutants obtained as a result of the measured data were compared to the limit values defined in the Stage V emission norm, for which the tested vehicle received the type approval.

In order to present the differences between the obtained measurement results, the article uses the proposed measurement procedure described in [6]. The two performed tests were characterized by a similar distribution of results, which can be seen thanks to the characteristics of the exhaust emission in time for each of the defined test phases. They confirmed the relation between the ecological indicators and the engine speed and load. The obtained results of the emission per second (lower by about 30\%) and the values of the specific emission (differences at the level of 10-20\%) indicate the advantage of the modified NRSC test. In terms of $\mathrm{CO}$ and $\mathrm{PM}$ emissions, the Stage $\mathrm{V}$ emission standard was met, while the $\mathrm{HC}$ and $\mathrm{NO}_{\mathrm{x}}$ indicators were exceeded. Special attention should be brought to the last of the given toxic compounds, because normally this compound's emission in real operating conditions most often reaches different - higher values, as compared to stationary tests.

The modified test procedure used by the authors allows for testing vehicles equipped with engines in their entire operating range of rotational speed as well as those operating at a constant rotational speed. Thanks to its versatility, it is possible to implement this solution for engines installed in all off-road vehicles. Therefore, further work of the authors will concern similar considerations and tests done for other machines of this category. In addition, plans are considered for conducting measurements on a wider group of vehicles in order to create a new original research test proposal.

\section{Nomenclature}

$\mathrm{CO}$ carbon monoxide

$\mathrm{CO}_{2} \quad$ carbon dioxide

DOC diesel oxidation catalyst

DPF diesel particulate filter

EGR exhaust gas recirculation

GHG greenhouse gas

$\mathrm{HC}$ hydrocarbons

$\mathrm{NO}_{\mathrm{x}} \quad$ nitrogen oxides

NRMM non-road mobile machinery
NRSC non-road stationary cycle

PEMS portable emissions measurement systems

PM particulate matter

PTO power take-off

RDE real driving emissions

SCR selective catalytic reduction

VGT variable turbo geometry

WHO World Health Organization

\section{Bibliography}

[1] COMMISSION DIRECTIVE 2010/26/EU of 31 March 2010 amending Directive 97/68/EC of the European Parliament and of the Council on the approximation of the laws of the Member States relating to measures against the emission of gaseous and particulate pollutants from internal combustion engines to be installed in non-road mobile machinery.

[2] COMMISSION DIRECTIVE 2012/46/EU of 6 December 2012 amending Directive 97/68/EC of the European Parliament and of the Council on the approximation of the laws of the Member States relating to measures against the emission of gaseous and particulate pollutants from internal combustion engines to be installed in non-road mobile machinery.

[3] Delphi Technologies. Worldwide emissions standards. On and off-highway commercial vehicles, 2018/2019.
[4] DIRECTIVE 2004/ 26/EC OF THE EUROPEAN PARLIAMENT AND OF THE COUNCIL of 21 April 2004 amending Directive 97/68/EC on the approximation of the laws of the Member States relating to measures against the emission of gaseous and particulate pollutants from internal combustion engines to be installed in non-road mobile machinery.

[5] European Environment Agency. European Union Emission Inventory Report 1990-2016; Publications Office of the European Union: Luxembourg, 2018., European Environment Agency. Greenhouse Gas Emissions from Transport in Europe; European Environment Agency: Copenhagen 2019.

[6] LIJEWSKI, P. Studium emisji związków toksycznych spalin z silników o zastosowaniach pozadrogowych. Rozprawa ha- 
bilitacyjna. Wydawnictwo Politechniki Poznańskiej. Poznań 2013.

[7] LIJEWSKI, P., MERKISZ, J., FUĆ, P. et al. Air pollution by the exhaust emissions from construction machinery under actual operating conditions. Applied Mechanics and Materials. 2013, 390, 313-319.

https://doi.org/10.4028/www.scientific.net/AMM.390.313

[8] KAMIŃSKA, M., RYMANIAK, Ł., DASZKIEWICZ, P. et al. Test guidelines for evaluation real driving emission twoway vehicles. MATEC Web of Conferences. 2019, 294, 02009-1-02009-8.

https://doi.org/10.1051/matecconf/ 201929402009

[9] KHAN, T., FREY, H.C. Comparison of real-world and certification emission rates for light duty gasoline vehicles. Science of the Total Environment. 2018, 622, 790-800. https://doi.org/10.1016/j.scitotenv.2017.10.286

[10] Manufacturer's technical data - agricultural tractors produced in 2018-2020.

[11] O'DRISCOLL, R., STETTLER, M.E.J., MOLDEN, N. et al. Real world $\mathrm{CO}_{2}$ and $\mathrm{NO}_{\mathrm{x}}$ emissions from 149 Euro 5 and 6 diesel, gasoline and hybrid passenger cars. Science of the Total Environment. 2018, 621, 282-290. https://doi.org/10.1016/j.scitotenv.2017.11.271

[12] Our World in Data Website. Available online https://ourworldindata.org (accessed on 05.2021).

[13] PATHAK, S.K., SOOD, V., SINGH, Y. et al. Real world vehicle emissions: Their correlation with driving parameters. Transportation Research Part D: Transport and Environment. 2016, 44, 157-176. https://doi.org/10.1016/j.trd.2016.02.001

[14] RYMANIAK, Ł., DASZKIEWICZ, P., MERKISZ, J. et al. Method of determining the locomotive engine specific fuel

\begin{abstract}
Michalina Kamińska, MEng. - Faculty of Civil and Transport Engineering, Poznan University of Technology.

e-mail:michalina.kaminska@put.poznan.pl
\end{abstract}

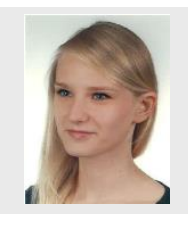

Paweł Daszkiewicz, DEng. - Łukasiewicz Research Network - Rail Vehicle Institute "TABOR", Poland. e-mail: pawel.daszkiewicz@tabor.lukasiewicz.gov.pl consumption based on its operating conditions. AIP Conference Proceedings. 2019, 2078(1), 020053-1-020053-8. https://doi.org/10.1063/1.5092056

[15] RYMANIAK, Ł., LIJEWSKI, P., KAMIŃSKA, M. et al. The role of real power output from farm tractor engines in determining their environmental performance in actual operating conditions. Computers and Electronics in Agriculture. 2020, 173, 105405-1-105405-7. https://doi.org/10.1016/j.compag.2020.105405

[16] SCHROEDER, F., BREUER, B., PREISS, H., WEIDHAAS, G. Motorcycle noise and exhaust emissions-statutory testing methods versus real traffic situations. presented at the small engine technology. SAE Technical Paper 1999-013255. 1999. https://doi.org/10.4271/1999-01-3255

[17] SIEDLECKI, M., SZYMLET, N., LIJEWSKI, P. et al. Emissions from NRMM vehicles in real operating conditions in relation to the number of vehicles in use in the Poznan city agglomeration. SAE Technical Paper 2020. 202001-2218. https://doi.org/10.4271/2020-01-2218

[18] THOMAS, D., LI, H., WANG, X. et al. A comparison of tailpipe gaseous emissions for RDE and WLTC using SI passenger cars. SAE Technical Paper 2017-01-2391. https://doi.org/10.4271/2017-01-2391

[19] TSAI, J.-H., CHIANG, H.-L., HSU, Y.-C. et al. Development of a local real world driving cycle for motorcycles for emission factor measurements. Atmospheric Environment. 2005, 39, 6631-6641. https://doi.org/10.1016/j.atmosenv.2005.07.040

[20] World Health Organization Website. Available online: http://www.who.com (accessed on 05.2021).

Maciej Andrzejewski, DEng. - Łukasiewicz Research Network - Rail Vehicle Institute "TABOR", Poland. e-mail:maciej_andrzejewski@op.pl
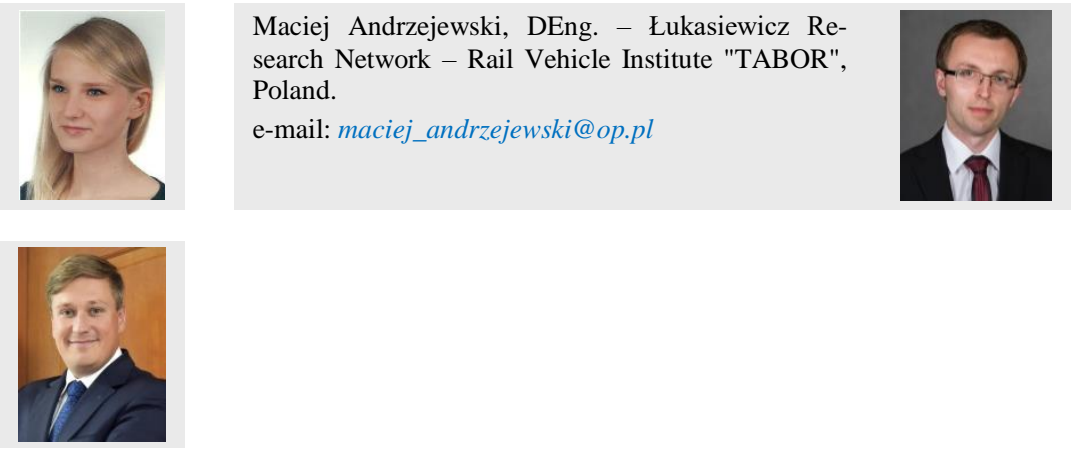